\title{
Comprehensive Analysis of PPP Financing Mode
}

\author{
$\mathrm{Li} \mathrm{Xu}$ \\ Xinjiang Vocational and Technical College of Communications \\ Urumqi, China 831401
}

\begin{abstract}
The PPP financing mode is "Public-PrivatePartnership" type, and it is defined by broad and narrow meanings. This paper focuses on three different types of outsourcing, franchise and privatization in the narrow classification of PPP mode, as well as their modes, characteristics and contract durations, further analyses the connotation of the PPP mode as a new project financing mode, which can make more private capital involved in projects to improve efficiency and reduce risks, and to guarantee the private capital to be "profitable". On the premise of reduction of the initial investment burden and risks of the government, the PPP mode improves the quality of urban rail transit services.
\end{abstract}

Keywords-PPP financing mode; broad and narrow classification; connotation

\section{INTRODUCTION}

\section{A. The Emergence and Development of PPP Financing Mode}

After the 1990s, as a new financing mode, the PPP mode (Public-Private-Partnership), has became popular in Western countries, especially in Europe, and it plays an important role in the field of public infrastructure, especially in the construction of large-scale, one-off projects such as roads, railways, and subways.

The term PPP investment and financing mode was proposed by the British government in 1982 and is popular in Europe, and at present, it gets an extensive attention and a wide application in more and more regions and countries. Seventy-five percent of government managers in the UK believe that projects under the PPP mode meet and exceed the requirements for relationship between price and quality, saving $17 \%$ of the funds. $80 \%$ of the projects are completed according to the specified construction period, but only $30 \%$ of the regular bidding projects are completed on time and $20 \%$ are not completed on time, with the longest delay no more than 4 months. At the same time, $80 \%$ of the project cost is in the scope of budget, but that under the traditional bidding method can only reach $25 \%$; and $20 \%$ beyond the budget is resulted from the governmental proposal for project scheme adjustment. According to the UK experience, the projects applicable to the PPP mode include: transportation (roads, railways, airports, and ports), health (hospitals), public safety (prisons), national defense, education (schools), and public real estate management. Chile introduced the PPP mode in 1994 under an urgent need to balance the infrastructure investment and improve the utilities, by which, the modernization of infrastructure is increased and the availability of sufficient funds to investment in social development plans is achieved. 36 projects have been completed with an investment of 6 billion US dollars, including 24 traffic fields, 9 airports, 2 prisons, and 1 reservoir, with the annual investment scale increased to US\$1.7 billion from US\$300 million before the implementation of the mode. Portugal started the PPP mode in 1997 and first applied it to the construction of the road network. During the 10-year period to 2006, the road mileage doubled. In addition to roads, ongoing projects also include the construction and operation of hospitals, the construction of railways and urban subways. In December 2004, Brazil passed the "Public-Private Partnership (PPP) Mode" Act, which provides specific regulations on the project bidding and contracting under the PPP mode implemented by national management departments. According to the Brazilian Ministry of Planning, 23 roads, railways, ports and irrigation projects already included in the 2004-2007 four-year development plan will be the first bid projects for the PPP mode, with a total investment of BRL USD 13.067 billion.

\section{B. The Meaning of PPP Mode}

PPP mode is the abbreviation of Public-Private-Partnership, which refers to the partnership between government and private organizations, in order to cooperate in the construction of urban infrastructure projects, or to provide certain public goods and services, based on the concession agreement, for which a contract is signed to clarify the rights and obligations of parties to ensure the smooth completion of the cooperation, and ultimately to enable the parties to achieve more favorable results than that is expected from individual actions. 


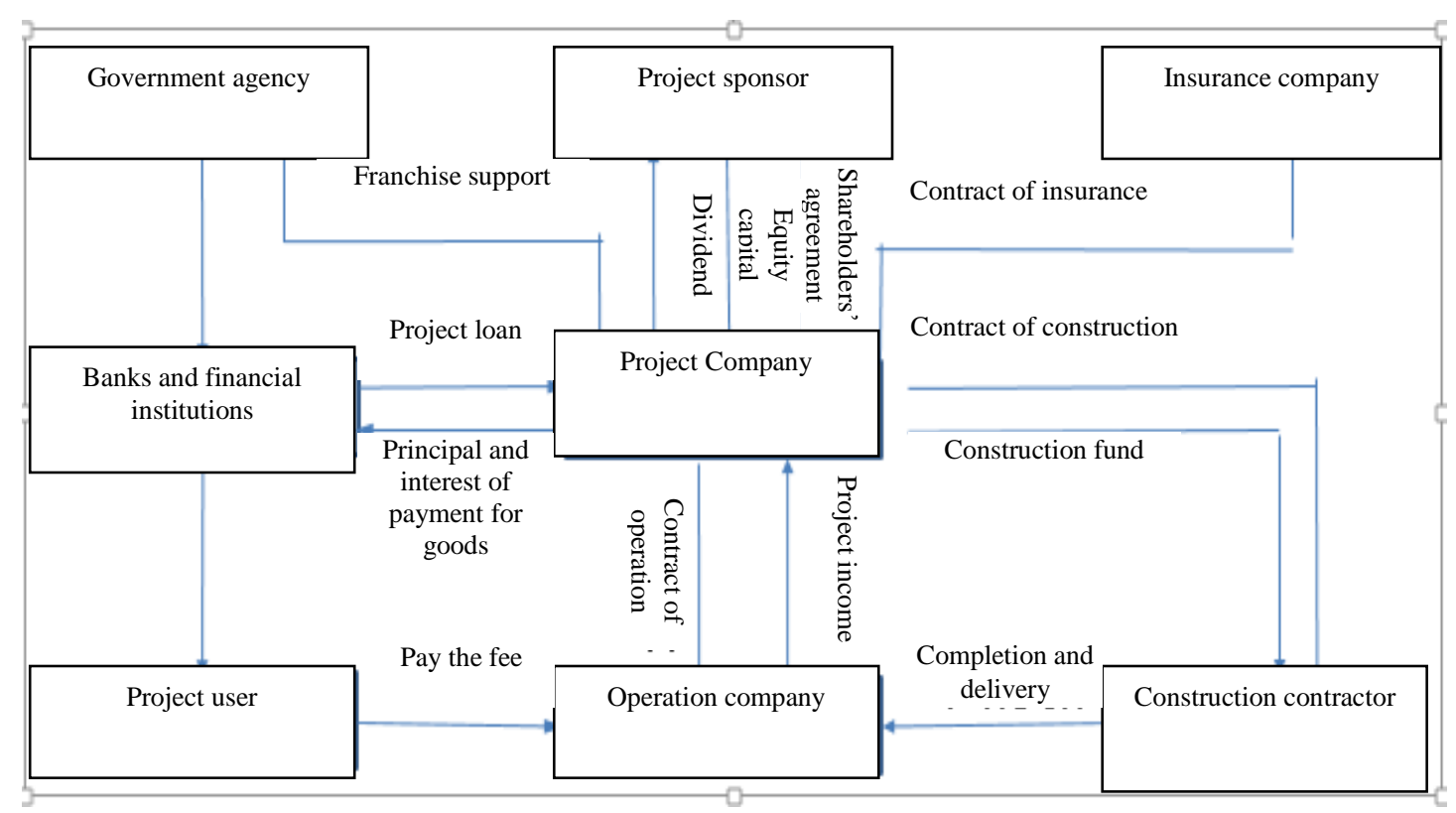

Fig. 1. PPP mode structure.

The PPP mode is very complex, and may include private for-profit businesses, private non-profit organizations, and public non-profit organizations (such as governments), among whom there will be inevitably divergences of different levels and types on interests and responsibilities, so Only a mechanism of mutual cooperation among the government and private enterprises can make the differences among the parties fuzzed, and further make the objectives of the project can be completed on the premise of seeking common ground while reserving differences.

The organizational level of the PPP mode is like a pyramid. At the top of the pyramid is the government. It is the policy maker who introduces the private sectors to participate in infrastructure construction projects. The government has a complete policy framework, objectives and implementation strategies for infrastructure construction projects, guiding and constraining the participants in the construction and operation of the projects. The central part of the pyramid is a government agency responsible for interpreting and applying government policy guidelines to form specific project objectives; at the bottom of the pyramid are private participants in the projects, and by signing a long-term agreement or contract with the relevant government department, coordinate the relationship among their objectives, policy objectives and the specific objectives of the relevant government agencies, by which the intended goals are achieved as far as possible during the process of project.

One of the most striking features of this mode is the coordination among the government or its affiliates and the investors and operators of the project as well as its function in project construction. The PPP mode is a complete concept of project financing, but not a complete change of project financing, and it is a new model of the organizational setup during the project life cycle. It is a form of mutual cooperation among government, for-profit enterprises and non-profit enterprises based on a "win-win" or "multi-win" concept for a project, to make participants achieve more favorable results than expected from individual actions. The operation idea is shown in "Fig. 1". Although the participants have not achieved the maximum benefit at their ideals, the total income, that is, the social benefits, is the largest, which is obviously more in line with the purpose of public infrastructure construction.

\section{THE CLASSIFICATION OF PPP MODE}

With reference to the classification methods of the World Bank and the Canadian PPP National Committee, combined with the current domestic application status, the PPP mode has broad and narrow meanings. Broad PPP refers to the contractual relationship among the government and the social sectors to provide public goods. It is considered to be a cooperative mode in which all parties involved jointly share the risks for the public services such as urban infrastructure projects. Narrow PPP refers to the generic term of various financing modes, including BOT, TOT, DBFO and other modes. The narrow PPP more emphasizes the risk sharing mechanism and the project measurement value principle in the cooperation process. Specifically, it can be divided into three categories: outsourcing, franchise and privatization as in "Table I".

Outsourcing is divided into module outsourcing (service outsourcing, management outsourcing) and integrative outsourcing. PPP projects are generally funded by the government, and one or several functions of the entire project is contracted by private sectors, e.g. they only undertake the project construction, or manage maintenance facilities or provide partial public services by commission of the government, and realize gains through governmental payments. In the PPP projects of outsourcing, the private sectors bear relatively little risk. 
The franchise category requires the private sectors to work with the public sectors to jointly share gains and risks, and it is divided into TOT, BOT and many other modes. It requires the projects must be invested partially or wholly by private sectors, and the project risks and benefits are shared together with the public sectors through certain cooperation mechanisms. According to the actual income of the project, the public sector may charge the franchise company a certain franchise fee or give certain compensation, which requires the public sector to coordinate the balance between the profit of the private sector and the public welfare of the project. Therefore, the success of franchise projects depends to a large extent on the management level of relevant government departments. By establishment of an effective regulatory mechanism, franchise projects can give full play to their respective advantages, save the construction and operation costs of the entire project and at the same time improve the quality of public services. The assets of the project are retained ultimately by the public sector, so there is generally a transfer of permission and ownership, that is, it requires the private sector to transfer the permission or ownership of the project to the public sector after the completion of the contract.

In the privatization category, private sectors are responsible for all projects, and public sectors responsible for supervision and management. It is divided into full privatization and partial privatization. The PPP project requires the private sectors to be responsible for the full investment of the project, and under the supervision of the government, charge the users for investment recovery and profits achievement. The ownership of the PPP projects of privatization category is permanently owned by private sectors, without the characteristics of limited recourse, so the private sectors have the greatest risk in such PPP projects.

TABLE I. CATEGORIES AND CHARACTERISTICS OF PPP MODE

\begin{tabular}{|c|c|c|c|c|c|c|}
\hline \multicolumn{3}{|c|}{ Mode } & $\begin{array}{c}\text { English } \\
\text { Meaning }\end{array}$ & Chinese Meaning & Characteristics & $\begin{array}{c}\text { Contract } \\
\text { Term }\end{array}$ \\
\hline \multirow{4}{*}{ Outsourcing } & \multirow{2}{*}{$\begin{array}{l}\text { Module } \\
\text { outsourcing }\end{array}$} & $\mathrm{SC}$ & $\begin{array}{l}\text { Service } \\
\text { Contract }\end{array}$ & Service Outsourcing & $\begin{array}{l}\text { The government entrusts the private sectors to } \\
\text { provide a public service at a certain cost, such as } \\
\text { equipment maintenance and sanitation cleaning. }\end{array}$ & $1-3$ years \\
\hline & & MC & $\begin{array}{l}\text { Management } \\
\text { Contract }\end{array}$ & $\begin{array}{l}\text { Management } \\
\text { outsourcing }\end{array}$ & $\begin{array}{l}\text { The government entrusts the private sector to } \\
\text { manage a public service at a certain cost, such as } \\
\text { rail transit operations and urban waste disposal. }\end{array}$ & $3-5$ years \\
\hline & \multirow[t]{2}{*}{$\begin{array}{l}\text { Overall } \\
\text { outsourcing }\end{array}$} & DB & Design- Build & Design- construction & $\begin{array}{l}\text { The private sector designs and builds infrastructure } \\
\text { at a fixed price agreed in advance, in accordance } \\
\text { with performance indicators set by the public } \\
\text { sector, and bears the risk of project delays and cost } \\
\text { overruns. Therefore, the private sector must meet } \\
\text { the required performance indicators by improving } \\
\text { its management and professional skills. }\end{array}$ & uncertain \\
\hline & & DBMM & $\begin{array}{l}\text { Design-- Build- } \\
\text { Major } \\
\text { Maintenance }\end{array}$ & $\begin{array}{l}\text { Design } \\
\text { construction- } \\
\text { maintenance }\end{array}$ & $\begin{array}{l}\text { The public sector is responsible for the operational } \\
\text { of the infrastructure, and the private sector is } \\
\text { primarily responsible for the maintenance functions } \\
\text { of the infrastructure. }\end{array}$ & uncertain \\
\hline \multirow{4}{*}{ Franchise } & \multirow[t]{2}{*}{ TOT } & PUOT & $\begin{array}{l}\text { Purchase- } \\
\text { Upgrade- } \\
\text { Operate-- } \\
\text { Transfer }\end{array}$ & $\begin{array}{l}\text { Purchase-update- } \\
\text { operation-transfer }\end{array}$ & $\begin{array}{l}\text { The private sector purchases existing public } \\
\text { infrastructure and operates the facilities after } \\
\text { certain renewal and expansion. During the } \\
\text { operation period, the private sector owns the } \\
\text { ownership of the facilities, and after the contract is } \\
\text { over, the right to use and ownership of the facilities } \\
\text { is transferred to the public sector. }\end{array}$ & $8-15$ years \\
\hline & & LUOT & $\begin{array}{l}\text { Lease-- } \\
\text { Upgrade- } \\
\text { Operate-- } \\
\text { Transfer } \\
\end{array}$ & $\begin{array}{l}\text { Lease-update- } \\
\text { operation-transfer }\end{array}$ & $\begin{array}{l}\text { The private sector purchases existing public } \\
\text { infrastructure and operates the facilities after } \\
\text { certain renewal and expansion, and after the lease } \\
\text { period, transfer them to the public sector. }\end{array}$ & $8-15$ years \\
\hline & \multirow[t]{2}{*}{ BOT } & BLOT & $\begin{array}{l}\text { Build- Lease- } \\
\text { Operate- } \\
\text { Transfer }\end{array}$ & $\begin{array}{l}\text { Construction-lease- } \\
\text { operation-transfer }\end{array}$ & $\begin{array}{l}\text { The governmental department first signs a long- } \\
\text { term lease contract with the public sector, and then } \\
\text { the private sector makes investment and } \\
\text { construction of infrastructure on the public land, } \\
\text { and operates the facilities during the lease period, } \\
\text { to recover investment and achieve profits by } \\
\text { charging users. After the contract is over, the } \\
\text { private sector transfer the facilities to the public } \\
\text { sector. }\end{array}$ & $\begin{array}{l}25-30 \\
\text { years }\end{array}$ \\
\hline & & ВОOТ & $\begin{array}{l}\text { Build- Own- } \\
\text { Operate- } \\
\text { Transfer }\end{array}$ & $\begin{array}{l}\text { Construction- } \\
\text { possess-operation- } \\
\text { transfer }\end{array}$ & $\begin{array}{l}\text { After obtaining the concession authorized by the } \\
\text { public sector, the private sector invests and } \\
\text { constructs the infrastructure, recovers the } \\
\text { investment and achieves profit by charging users. } \\
\text { The private sector has ownership of the facilities } \\
\text { during the concession period and returns it to the } \\
\text { public sector after the concession period. }\end{array}$ & $\begin{array}{l}25-30 \\
\text { years }\end{array}$ \\
\hline
\end{tabular}




\begin{tabular}{|c|c|c|c|c|c|c|}
\hline \multicolumn{3}{|c|}{ Mode } & $\begin{array}{c}\text { English } \\
\text { Meaning }\end{array}$ & Chinese Meaning & Characteristics & $\begin{array}{c}\text { Contract } \\
\text { Term }\end{array}$ \\
\hline \multirow[b]{2}{*}{ Franchise } & \multirow[b]{2}{*}{ Other } & DBTO & $\begin{array}{l}\text { Design-- Build- } \\
\text { Transfer-- } \\
\text { Operate }\end{array}$ & $\begin{array}{l}\text { Design-build- } \\
\text { transfer-operation }\end{array}$ & $\begin{array}{l}\text { The private sector first invests in the construction } \\
\text { of infrastructure, and after completion of the } \\
\text { construction, transfers it to the public sector at the } \\
\text { agreed price; the public sector then leases the } \\
\text { facilities back to the private sector at a certain cost, } \\
\text { and the private sector operates the facilities. The } \\
\text { purpose of doing so for the private sector is to } \\
\text { avoid various responsibilities or other complex } \\
\text { issues arising from the ownership of assets. }\end{array}$ & $\begin{array}{l}20-25 \\
\text { years }\end{array}$ \\
\hline & & $\mathrm{DBFO}$ & $\begin{array}{l}\text { Design-- Build- } \\
\text { Finance-- } \\
\text { Operate }\end{array}$ & $\begin{array}{l}\text { Design-build- } \\
\text { investment- } \\
\text { operation }\end{array}$ & $\begin{array}{l}\text { The private sector invests in the construction of } \\
\text { public facilities, and usually also has the ownership } \\
\text { of the facility; according to the contract, the public } \\
\text { sector pays the private sector a certain amount for } \\
\text { use of the facility, while it will provide the core } \\
\text { services associated with the facility, and the private } \\
\text { sector only provides the auxiliary service of the } \\
\text { facility, e.g. the private sector invests in the } \\
\text { construction of various hospital buildings, the } \\
\text { public sector pays a fee to the private sector to use } \\
\text { the built hospital facilities, provides major public } \\
\text { services such as outpatient services, and the private } \\
\text { sector is responsible for providing food, cleaning, } \\
\text { and other auxiliary services to ensure the normal } \\
\text { operation of the facility. }\end{array}$ & $\begin{array}{l}20-25 \\
\text { years }\end{array}$ \\
\hline \multirow{4}{*}{$\begin{array}{l}\text { privatization } \\
\text { category }\end{array}$} & \multirow[t]{2}{*}{$\begin{array}{l}\text { Full } \\
\text { privatization }\end{array}$} & PUO & $\begin{array}{l}\text { Purchase- } \\
\text { Upgrade- } \\
\text { Operate }\end{array}$ & $\begin{array}{l}\text { Purchase-update- } \\
\text { operation }\end{array}$ & $\begin{array}{l}\text { The private sector purchases the existing } \\
\text { infrastructure, operates it after renewal and } \\
\text { expansion, and permanently owns the property of } \\
\text { the facility. In the purchase contract signed with the } \\
\text { public sector, the mandatory public welfare } \\
\text { guaranty under governmental control and } \\
\text { supervision is stated. }\end{array}$ & Permanent \\
\hline & & $\mathrm{BOO}$ & $\begin{array}{l}\text { Build- } \\
\text { Operate }\end{array}$ & $\begin{array}{l}\text { Construction- } \\
\text { possess-operation }\end{array}$ & $\begin{array}{l}\text { The private sector invests, builds and permanently } \\
\text { owns and operates an infrastructure, and in the } \\
\text { original contract signed with the public sector, the } \\
\text { mandatory public welfare guaranty under } \\
\text { governmental control and supervision is stated. }\end{array}$ & Permanent \\
\hline & \multirow[b]{2}{*}{$\begin{array}{l}\text { Partial } \\
\text { privatization }\end{array}$} & \multicolumn{3}{|c|}{ Equity transfer } & $\begin{array}{l}\text { The public sector transfers part of the ownership of } \\
\text { existing facilities to the private sector, but the } \\
\text { public sector is generally still in a controlling } \\
\text { position, with the public and private sectors sharing } \\
\text { all risks. }\end{array}$ & Permanent \\
\hline & & \multicolumn{3}{|c|}{ Joint-ventured construction } & $\begin{array}{l}\text { The public sector and the private sector jointly fund } \\
\text { the construction of public facilities. The private } \\
\text { sector owns facilities through shareholding and } \\
\text { regulates the facilities by electing board members. } \\
\text { The public sector is generally in a controlling } \\
\text { position and bears risks together with the private } \\
\text { sector. }\end{array}$ & Permanent \\
\hline
\end{tabular}

\section{The CONNOTATION OF THE PPP Mode}

First, PPP is a new type of project financing mode. Project PPP financing is a project-based financing activity, and an implementation form of project financing, which mainly arranges financing according to the expected income of the project, assets and the force of governmental support measures rather than the credits of project investors or promoters. The direct benefits of project operation and the benefits transformed from governmental support are the source of funds for repayment of loans. The assets of the project company and the limited commitment granted by the government are the security guarantees for loans.

Second, the PPP financing mode can make more private capital involved in the project to improve efficiency and reduce risks, which is also wanting for the current project financing mode. The government's public sector and private enterprises make full-course cooperation on the basis of the concession agreement, and the parties are jointly responsible for the entire cycle of the project operation. The operation rules of PPP mode enable private enterprises to participate in the confirmation, design, feasibility study and other preliminary work of urban rail transit projects, which not only reduces the investment risk of private enterprises, but also makes the private enterprises introduce their more efficient management method and technologies of investment and construction into the project, effectively realize the control of project construction and operation, consequently beneficial to the risk reduction of project construction and investment and the interests guarantee of both governmental and private parties. This has the practical significance for shortening the project construction cycle, reducing the project operation cost and even the asset-liability ratio. 
Third, the PPP mode can make private capital "profitable" to a certain extent. The private sector's investment objective is to find projects that can both repay loans and return on investment, and unprofitable infrastructure projects are not attracting investment from private capital. With the PPP mode, the government can give private investors the corresponding policy support as compensation, thus solving this problem, such as tax incentives, loan guarantees, giving priority to the development of land along the line for private enterprises; by implementation of these policies, the enthusiasm of private enterprises can be promoted to invest their capital in urban rail transit projects.

Fourth, the PPP mode improves the quality of urban rail transit services on the premise of reducing the investment burden of the government and the risks in the initial construction. With the PPP mode, the public sector and private enterprises jointly participate in the construction and operation of urban rail transit, and private enterprises are responsible for project financing, which may increase the amount of capital of the project, and accordingly reducing the high asset-liability ratio, saving the investment of the government and transferring partial risk of project to the private enterprise, thus reducing the risk of the government. At the same time, the two sides can form a mutually beneficial long-term goal to better serve the society and the public.

\section{CONCLUSION}

In summary, the PPP model is a brand-new financing model. Since 2003, it has been promoted and applied in many areas of China, such as power supply, water, highways, bridges and other infrastructure construction. Governments at all levels attach great importance to it, all sectors of society provide strong support and private capital has been effectively utilized, which solve the problems of government funding, management difficulties, and risk sharing. It has been widely used in many areas of China.

\section{REFERENCES}

[1] Zhang Xiaofu. The Scope of Application and Selection Principle of PPP Mode [J]. Monthly Finance and Accounting, 2018 (03): 53-58.

[2] Jing Shilong, Wang Junhao. Research on the Development Strategy of China PPP Mode Based on Dynamic Mechanism [J]. Economics and Management Research, 2018 (04): 136-144.

[3] Wei Chunfei, The Development and Suggestions of PPP Mode in China [J]. Qinghai Finance, 2018(01): 30-32.

[4] Nie Yong, The Challenges and Countermeasures of PPP Mode under the New Normal [J]. Finance and Accounting, 2018(01): 169-170.

[5] Huang Dehong, Wei Kunshang, Yang Zhangxun. Problems and Countermeasures in the Development of PPP Mode in China [J]. Cooperative Economy and Technology, 2018(02): 54-56.

[6] Gao Meng. The Application of PPP Mode under Current Market Conditions in China and its Impact on Education and Training Industry Based on SWOT-PEST Analysis Model [J].Industrial Economy, 2018(01):67-70

[7] Cai Jufang, Cong Rong, Xue Hui. Research on Financial Management of BOT Project Based on PPP Mode [J].Financial Management, 2018(03):146-147.

[8] Li Chunxia. Discussion on the Problems and Strategies of PPP Mode Application under the Background of Supply-Side Structural Reform [J]. Financial Sector,2018(01):108-110.
[9] Xiang Ling, Study on the Existing Problems of "One Belt, One Road" in the PPP mode and Its Countermeasures [J]. Management Exploration, 2018 (01): 29-31.

[10] Peng Zijuan. Review on PPP Policies of 2017 [J]. Industry Observation, 2018: 7-9. 